\title{
MOTIVASI ORANG TUA MENYEKOLAHKAN ANAKNYA DI MADRASAH IBTIDAIYAH NEGERI (MIN) KARANG BARU MATARAM
}

\author{
Oleh: Aqodiah
}

\begin{abstract}
Abstrak
Mengenyam pendidikan merupakan suatu hal yang wajib bagi seluruh generasi bangsa ini, karena kita masih tergolong negara yang rendah dalam pendidikan, walaupun demikian halnya, masyarakat Indonesia pada umumnya dan khususnya di Mataram Nusa Tenggara Barat tidak putus harapan untuk mengejar ketertinggalan dari negara-negara lain. Dan yang menjadi cirri khas pendidikan yang paling penting sebagai corak pendidikan di Indonesia adalah adanya pendidikan madrasah ibtidaiyah (MI) yang sejajar dengan sekolah dasar (SD). Walaupun sekolah dasar lebih dahulu berdiri, tetapi madrasah ibtidaiyah mampu mengimbangi dengan berbagai macam kemajuan yang dicapai baik dari segi kualitas maupun kuantitas peserta didik.

Inilah yang menjadi kajian penting dalam artikel ini yakni motivasi orang tua yang menyekolahkan anaknya di MIN Karang Baru Mataram adalah terletak pada beberapa point di bawah ini:Kurikulum madrasah yang mengacu pada pembelajaran yang berbasis pada keterpaduan antara bidang studi umum dan agama yang berada di bawah naungan Kementrian Pendidikan Nasional dan Kementrian Agama RI. Sistim akademik yang menjadi nilai tambah bagi MIN Karang baru Mataram yaitu sistim Qiroaty yang diprogramkan sebagai wahana pembinaan pembacaan al-Qur'an sesuai tingkat atau kelas para siswa yang dilaksanakan tiga puluh menit sebelum pelajaran dimulai, dari pukul 07.00-07.30, dan dilengkapi dengan program praktek amal ibadah, disiplin dalam setiap aturan sekolah. Adapun yang menjadi harapan orang tua pada dasarnya tercermin dari sistem kurikulum madrasah dalam arti orang tua mengharapkan putra-putrinya memiliki ilmu agama dan umum yang menjadi bekal dasar untuk melanjutkan pada jenjang pendidikan yang lebih tinggi dan dapat menjaga diri dalam pergaulan di masyarakat.
\end{abstract}

Kata Kunci: Motivasi, Menyekolahkan Anaknya, Madrasah Ibtidaiyah Negeri 


\section{A. PENDAHULUAN}

Dalam kehidupan satu bangsa, pendidikan memang mempunyai peran yang amat penting untuk menjamin perkembangan dan kelangsungan bangsa bersangkutan (UU No.2 Tahun 1989). Dan begitu pula dalam kehidupan sehari-hari seseorang tidak bisa terlepas dari satu aktivitas, baik untuk kehidupan sebagai makhluk sosial maupun sebagai makhluk to'at kepada Tuhan, untuk itu seseorang harus memiliki kemampuan dan keahlian dalam menjalankan aktivitas tersebut.

Dalam hal ini, orang tua memilki peran yang sangat penting untuk memberikan bekal bagi anak-anaknya untuk menjalani kehidupannya setelah ia dewasa nanti dengan ilmu pengetahuan yang lengkap, dengan harapan orang tua anak-anaknya menjadi generasi yang beriman, beriilmu, berakhlakul karimah dan berguna bagi nusa dan bangsa. Terkait dengan hal tersebut dalam al-Qur'an dijelaskan agar kita meminta keselamatan di dunia dan diakhirat. Sesuai dengan firman Allah SWT :

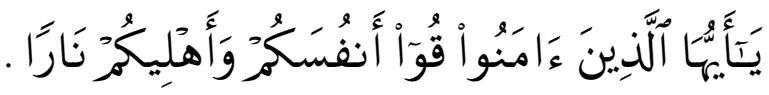

Artinya : Hai orang-orang yang beriman, peliharalah dirimu dan keluargamu dari ancaman api neraka. (At-tahrim: 6) ${ }^{1}$.

Terkait dengan hal tersebut Rasulullah bersabda yang Artinya : Dari Abi Hurairah R.a berkata : Rasulullah SAW bersabda setiap anak dilahirkan atas fitrah (kesucian agama yang sesuai dengan naluri) sehingga lancar lidahnya, maka kedua orang tuanyalah yang menjadikan dia Yahudi atau Nasrani atau majusi.(H.R. Bukhari Muslim). Menurut konsep hadits ini, maka orang tualah yang menjadikan anaknya baik.Ketika anak disekolahkan, hampir saja semua pengaruh pendidikan anak di sekolah bukan hanya dari segi kognitif

\footnotetext{
${ }^{1}$ Departemen Agama RI, Al-Qur'an tajwid dan Terjemahan, 2013, (Bandung: Diponegoro), hlm, 560.
} 
saja akan tetapi terus berlanjut ke afektif dan psikomotorik anak, sehingga anak dapat berbuat sesuai dengan ilmu pengtehuan yang diajarkan gurunya.

Tujuan pendidikan memuat gambaran tentang nilai-nilai yang baik, luhur, pantas, benar, dan indah untuk kehidupan. Karena itu tujuan pendidikan memiliki dua fungsi yaitu memberi arah kepada segenap kegiatan pendidikan dan merupakan sesuatu yang ingin dicapai oleh segenap kegiatan pendidikan. Dalam hal ini pendidikan yang mencakup dua aspek dapat diajarkan lebih mendalam pada pendidikan dasar khususnya di MI. Berdasarkan UndangUndang Republik Indonesia Nomor 20 Tahun 2003 tentang Sistim Pendidikan Nasional, pasal satu butir ke empat menyatakan " Madrasah Ibtidaiyah yang selanjytnya disebut MI adalah salah satu bentuk pendidikan formal yang menyelenggarakan pendidikan umum dengan kekhasan agama Islam pada jenjang pendidikan dasar, di dalam pembinaan Menteri Agama"². Berdasarkan hal itu pancasila sebagai Filsafat hidup bangasa sebagai hasil dari pengamalan nilai-nilai yang ada dalamal-Qur'an dan hadis akan mengarahkan kepada keseimbangan, baik dalam hubungan yang sifatnya rohaniah maupun jasmaniah. ${ }^{3}$

Berdasarkan konteks di atas pendidikan yang sifatnya integral antara aspek ruhani dan jasmani, bahwa penelitian ini perlu dilakukan karena terkait dengan Motivasi Orang Tua Menyekolahkan Anaknya di MIN Karang Baru Mataram. Kajian ini juga dianggap penting karena pada zaman ini pelajaran yang sifatnya agama sudah semakin berkurang dari perhatian masyarakat secara umum. Oleh karena itu, penelitian ini, menyuguhkan kajian terkait dengan motivasi pendidikan anak usia SD/MI yang dilengkapi dan disempurnakan dengan pendidikan agama yang dapat bermanfaat secara toeri dan praktek.

\footnotetext{
${ }^{2}$ Undang-Undang RI No. 20 Tahun 2003, dan SISDIKNAS, Peraturan Pemerintah RI, No. 47. Thn, 2008 tentang Wajib Belajar. 2009 ( Bandun: Rhusthi Phubliser), hlm. 164.

${ }^{3}$ Abdulloh Idi, Filsafat Pendidikan, Manusia, Filsafat dan Pendidikan, 2007 ( Jogjakarta: Arruz Media).HIm . 167
} 


\section{B. KAJIAN PUSTAKA}

\section{Pengertian Motivasi}

Istilah motivasi dalam dunia pendidikan sangat beraneka ragam mulai dari definisi, jenisnya dan tujuannya. Satu pemahaman Agama terkait dengan motivasi yaitu dalam hal beribdah, yaitu ada kita kenal istilah roja' (satu harapan akan pahala atau syurga dari Alloh, SWT setelah mengerjakan satu kewajiban yang Allah tetapkan pada satu kaum). Adapun ayat al-qur'an yang mengandung motivasi beribadah (bertaqwa) tersebut dalam surah Ar-Rahman ayat 46 sebagai berikut:

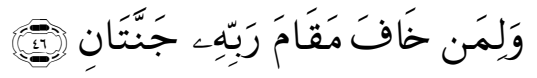

Artinya: Dan bagi orang yang takut akan saat menghadap Tuhannya ada dua syurga. (QS. Ar-Rahman; 46. (ada juga ahli tafsir yang berpendapat syurga dunia dan syurga akhirat). ${ }^{4}$

Motivasi berasal dari kata "motif" menunjukkan arti model atau mengapa seseorang berbuat sesuatu yang ditandai dengan munculnya feeling dan didahului dengan tanggapan adanya tujuan. ${ }^{5}$ Dengan kata lain bahwa motivasi itu jika dikaitkan dengan pendidikan dapat dimaknakan dengan kekuatan yang menjadi pendorong kegiatan individu untuk mencapai satu tujuan yang dapat menggugah semangat peserta didik untuk belajar dan mudah memahami materi dan dapat mempraktekkannya dalam kehidupan nyata. $^{6}$

Beberapa definisi tersebut sangat sesuai dengan kajian motivasi dalam lingkup pendidikan, khususnya motivasi orang tua menyekolahkan anaknya dilingkungan pendidikan yang berbasis Madrasah, dan lebih khususnya di Madrasah Ibtidaiyah (MI). Jadi motivasi dalam hal ini sebenarnya merupakan

${ }^{4}$ Depaq RI, Al-Qur'an dan Terjemahannya, Bogor: Sabiq: 2009

${ }^{5}$ Sardiman,Interaksi dan Motivasi Belajar, (Jakarta: Raja Grafindo. 2008), hlm. 73.

${ }^{6}$ Saiful Bahri, Psikologi Pembelajaran, ( Jakarta: Rineka Cipta, 2010). HIm 148. 
respon dari suatu aksi yang telah dilakukan oleh para pendidik yang dianggap sudah berhasil dalam melaksanakan tugasnya.

\section{Macam-macam Motivasi}

Motivasi sangat banyak jenisnya, akan tetapi jika dilihat dari dasar terbentuknya dapat dibagi dua yaitu; pertama; Motivasi bawaan dan yang ke dua; motivasi dari apa yang telah dipelajari atau diketahui. Motivasi bawaan ini dapat diartikan kareana adanya tuntutan kebutuhan yang sifatnya primer harus terpenuhi seperti makan, berkeluarga dan lainnya yang mendorong orang giat dan semangat bekerja. Adapun motivasi yang dipelajari maksudnya adalah terkait dengan hubungan social kemasyarakatan atau disebut dengan motivasi jasmaniyah dan motivasi rohaniah, atau dikenal dengan unsure ekstrinsik dan unsur intrinsik.

\section{Konsep Motivasi Orang Tua Menyekolahkan Anaknya}

Pengertian Minat menurut Tidjan (1976: 71) adalah gejala psikologis yang menunjukan pemusatan perhatian terhadap suatu obyeksebab ada perasaan senang. Sedangkan menurut Drs. Dimyati Mahmud (1982), minat sebagai akibat yaitu pengalaman efektif yang distimular oleh hadirnya seseorang atau sesuatu obyek, atau karena berpartisipasi dalam suatu aktifitas. Berdasarkan beberapa pengertian minat menurut ahli tersebutpenulis menyimpulkan bahwa minat adalah gejala psikologis yang menunjukanbahwa suatu obyek yang menarik perhatian dan menimbulkanperasaan senang sehingga cenderung kepada obyek tersebut.

Menurut Islam teori konvergensi yang dikemukakan oleh William Stern, menjelaskan bahwa pendidikan dipengaruhi oleh dua faktor, yaitu faktor bakat atau bawaan sejak lahir dan faktor lingkungan eksternal. Apa yang dikemukakan oleh ahli pendidikan di atas mendekati kebenaran, sebagaimana sabda Rasulullah yang Artinya : Dari Abi Hurairah R.a berkata : Rasulullah SAW bersabda setiap anak dilahirkan atas fitrah 
(kesucian agama yang sesuai dengan naluri) sehingga lancar lidahnya, maka kedua orang tuanyalah yang menjadikan dia Yahudi atau Nasrani atau majusi.(H.R. Bukhari Muslim). Menurut konsep hadits ini, maka orang tualah yang menjadikan anaknya baik.Ketika anak disekolahkan, hampir saja semua pengaruh pendidikan anak di sekolah bukan hanya dari segi kognitif saja akan tetapi terus berlanjut ke afektif dan psikomotorik anak, sehingga anak dapat berbuat sesuai dengan ilmu pengtehuan yang diajarkan gurunya. Jadi Minat orang tua menyekolahkan anaknya ke lembaga pendidikan agama berfungsi memelihara kelurganya terutama anaknya semoga terhindar dari segala macam ancaman baik di dunia mapun diakhirat kelak.

\section{Tanggung jawab orang Tua Menyekolahkan anaknya}

Orang tua memiliki tugas yang sangat kompleks setelah anaknya lahir selain mengasuhnya, menjaganya dan memberikan makanan yang bergizi untuk kesehatan jasmani atau fisiknya, orang tua juga harus memberikan nutrisi secara rohani dan akal untuk mendukung kesehatan fisik itu, sehingga terbentuk satu kesempurnaan dan keseimbangan pada diri anak itu, sehingga siap menjadi insane baru yang akan membawa misi penting bagi kemajuan Agama, Nusa Bangsa dan keluarga dan terutama pada diri anak itu sendiri. Oleh sebab itu orang tua memiliki satu tugas yang utama yaitu memberikan pendidikan sejak anak itu pada usia dini, hal ini dikisahkan dalam Al-Qur'an sebagai berikut:

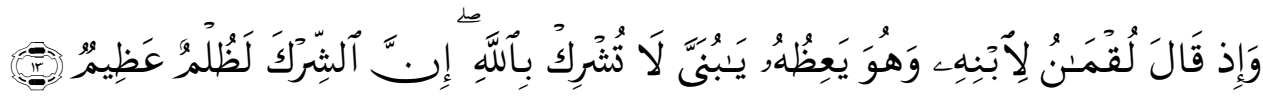

Dan (Ingatlah) ketika Luqman Berkata kepada anaknya, di waktuia memberi pelajaran kepadanya: "Hai anakku, janganlah kamumempersekutukan Allah, Sesungguhnya mempersekutukan (Allah) adalahbenar-benar kezaliman yang besar (QS. Lukman: 13). 
Dari ayat tersebut dapat kita ambil pokok pikiran sebagai berikut,pertama orang tua wajib memberi pendidikan kepada anak-anaknya.Kedua dalam mendidik prioritas pertama adalah penanaman akidah,pendidikan akidah diutamakan agar menjadi kerangka dasar dan landasandalam membentuk pribadi anak yang soleh.

Dengan ayat ini Allah Subhaanahu wa Ta'ala mengingatkan orangorangyang beriman, bahwa semata mata beriman saja belumlah cukup.Iman harus dipelihara, dirawat dan dipupuk dengan cara menjagakeselamatan diri dan seisi rumah tangga dari api neraka. Imam Al-Ghazali berkata, "Anak itu amanah Allah bagi keduaorangtuanya, hatinya bersih bagaikan mutiara yang indah bersahaja, bersihdari setiap lukisan dan gambar. Ia menerima setiap yang dilukiskan,cenderung ke arah apa saja yang diarahkan kepadanya. Jika ia dibiasakanbelajar dengan baik ia akan tumbuh menjadi baik, beruntung di dunia dandiakhirat. Kedua orangtuanya semua gurunya, pengajar dan pendidiknyasama-sama mendapat pahala. Dan jika ia dibiasakan melakukan keburukandan diabaikan sebagaimana mengabaikan hewan, ia akan celaka danrusak, dan dosanya menimpa pengasuh dan orang tuanya." Pendidikanyang baik merupakan pemberian terbaik orangtua kepada anak,sebagaimana sabda Rasulullah hallallahu 'alaihi wa sallam: "Tidak adapemberian orangtua kepada anak yang lebih utama daripada pendidikanyang baik." (HR.AtTirmidzy)

Adapun pendidikan yang harus diberikan oleh orangtua sebagaiwujud tanggung jawab terhadap keluarga adalah:

a. Pendidikan Agama.

Pendidikan agama dan spiritual adalah pondasiutama bagi pendidikan keluarga. Pendidikan agama ini meliputipendidikan aqidah, mengenalkan hukum halal-haram memerintahkananak beribadah (shalat) sejak umur tujuh tahun, mendidik anak untukmencintai Rasulullah Shallallahu 'alaihi 
wasallam, keluarganya,orang-orang yang shalih dan mengajar anak membaca Al-Qur'an. AlGhazali berkata, "Hendaklah anak kecil diajari Al-Qur'an hadits dansejarah orang-orang shalih kemudian hukum Islam.” b. Pendidikan Akhlaq.

Rasulullah Shallallahu 'alaihi wa sallambersabda, "Diantara kewajiban bapak kepada anaknya ialahmemperbagus budi pekertinya dan membaguskan namanya."(HR.Baihaqi). Para ahli pendidikan Islam menyatakan bahwapendidikan akhlak adalah jiwa pendidikan Islam, sebab tujuan tertinggipendidikan Islam adalah mendidik jiwa dan akhlak.

c. Pendidikan Jasmani.

Islam memberi petunjuk kepada kita tentangpendidikan jasmani agar anak tumbuh dan berkembang secara sehatdan bersemangat. Allah Ta'ala berfirman: Artinya: "Makanlah dan minumlah kamu tetapi jangan berlebih-lebihan,sesungguhnya Allah tidak senang kepada orang yangberlebih-lebihan." (QS.Al-A'raf:31).

d. Pendidikan Akal.

Yang dimaksud dengan pendidikan akal adalahmeningkatkan kemampuan intelektual anak, ilmu alam, teknologi dansains modern sehingga anak mampu menyesuaikan dengan kemajuanilmu pengetahuan dalam rangka menjalankan fungsinya sebagai hambaAllah dan khalifah-Nya, guna membangun dunia ini sesuai dengankonsep yang ditetapkan Allah. Hal inilah yang diisyaratkan oleh Allahdengan proses penciptaan nabi Adam AS dimana sebelum iaditurunkan ke bumi, Allah mengajarkan nama-nama (asma) yang tidakdiajarkan kepada para malaikat. (QS. Al-Baqarah : 31) Artinya: Dan Dia mengajarkan kepada Adam Nama-nama (bendabenda)seluruhnya, kemudian mengemukakannya kepada ParaMalaikat lalu berfirman: "Sebutkanlah kepada-Ku nama bendabendaitu jika kamu mamang benar orang-orang yang benar!" (QS. AlBaqarah : 31) 
e. Pendidikan Sosial.

Yang dimaksud dengan pendidikan sosial adalahpendidikan anak sejak dini agar bergaul di tengah-tengah masyarakatdengan menerapkan prinsipprinsip syari'at Islam. Di antara prinsipsyari'at Islam yang sangat erat berkaitan dengan pendidikan sosial iniadalah prinsip ukhuwwah Islamiyah. Rasa ukhuwwah yang benar akanmelahirkan perasaan luhur dan sikap positif untuk saling menolongdan tidak mementingkan diri sendiri. Islam telah menjadikanukhuwwah Islamiyah sebagai kewajiban yang sangat fundamental danmengibaratkan kasih sayang sesama muslim dengan sebatang tubuh,apabila salah satu anggota badannya sakit, maka yang lain ikutmerasakannya.

d. Memantau efektivitas jam belajar di sekolah.

Hal ini dapat dilakukandengan sering bertanya pada anak mengenai proses belajar mengajar disekolah, misalnya apakah sepanjang hari pelajarannya penuh atau adajam kosong, kalau ada jam kosong karena guru berhalangan hadirapakah ada tugas yang diberikan, apakah ada mata pelajaran yangsering sekali kosong, atau hanya mencatat terus, apakah gurunyamasuk dan keluar kelas tepat waktu, dan sebagainya. Apabila dariketerangan-keterangan anak ada yang menimbulkan tanda tanyaataupun ketidakpuasan, maka orang tua berhak menanyakan langsungke sekolah mengenai hal tersebut, dan berdiskusi dengan pihak sekolahuntuk mencari pemecahan masalahnya.

\section{Konsep atau system Kurikulum Pendidikan di Madrasah}

Proses pendidikan merupakan kegiatan memobilisasi segenap komponen pendidikan oleh pendidik terarah kepada pencapaian tujuan pendidikan. Bagaimana proses pendidikan itu dilaksanakan sangat menentukan kualitas hasil pencapaian tujuan pendidikan. Kualitas proses pendidikan menggejala pada dua segi, yaitu kualitas komponen dan kualitas pengelolaannya. Kedua segi tersebut satu sama lain saling tergantung. 
Walaupun komponen-komponennya cukup baik, seperti tersedianya prasarana dan sarana serta biaya yang cukup, juga ditunjang dengan pengelolaan yang andal maka pencapaian tujuan tidak akan tercapai secara optimal. Demikian pula bila pengelolaan baik tetapi di dalam kondisi serba kekurangan, akanmengakibatkan hasil yang tidak optimal.

Kurikulum di sebuah lembaga pendidikan agama tidak harus mempelajari ilmu-ilmu agama akan tetapi harus mengauasai ilmu-ilmu keduniaan di mana kelak siswa akan dapat menguasai berbagai aspek kehidupan shingga ia tidak menjadi muslim yang lemah dan tidak bedaya apa-apa akan tetapi sebaliknya. Hal ini sejalan dengan apa yang diungkapakan oleh Allah SWT dalam Al-Qur'an surah Al-Maidah ayat 51
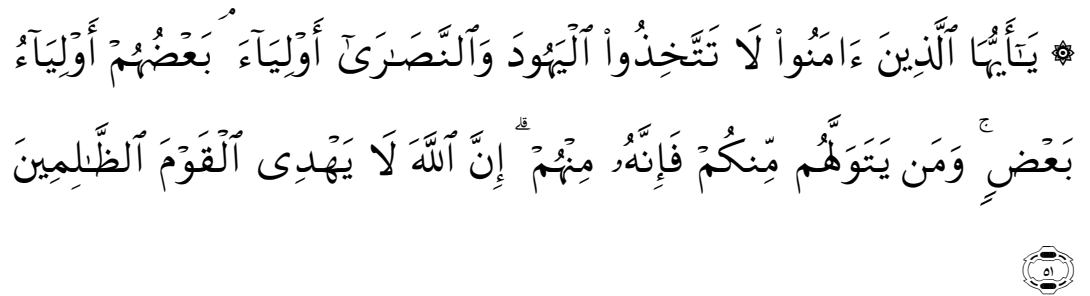

Artinya: " Hai orang-orang yang beriman, janganlah kamu mengambil orang-orang Yahudi dan Nasrani menjadi pemimpin-pemimpinmu, sebagain mereka adalah penolong bagi sebagian yang lain. Barang siapa diantara kamu mengambil mereka menjadi pemimpin, maka sesungguhnya orang itu termasuk golongan mereka. Sesungguhnya Allah SWT tidak akan memberi petunjuk kepada orang yang zalim”.(AlMaidah: 51).

Berdasarkan ayat di atas dapat dipahami bahwa kurikulum pendidikan harus dirancang berdasarkan kebutuhan terhadap pendidikan agama ditengah masyarakat dan kebutuhan pendidikan umum untuk mengahadapi tantangan zaman, sehingga umat Islam mampu menguasai ilmu pengetahuan yang positif disemua aspek kehidupan. 
Peserta didik berstatus sebagai subjek didik. Pandangan modern cenderung menyebut demikian oleh karena peserta didik (tanpa pandang usia) adalah subjek atau pribadi yang otonom, yang ingin diakui keberadaannya. Peserta didik mengalami pendidikannya dalam tiga lingkungan yaitu lingkungan keluarga, lingkungan sekolah, dan lingkungan masyarakat. Sebab itu yang bertanggung jawab terhadap pendidikan yaitu orang tua, guru, pemimpin program pembelajaran, pelatihan, dan masyarakat/organisasi

Kurikulm pendidikan ditingkat Madrasah Ibtidaiyah Negeri Karang Baru Mataram di samping memakai kurikulum Departemen Agama juga memakai kurikulum Departemen Pendidikan Nasional dan ditambah dengan kurikulum muatan lokal yang bernuanasa pesantren sehingga pemahaman anak terhadap agama tidak dangkal, sehingga diharapkan nanti ia dapat menyelesaikan semua persoalan agama terutama yang ada kaitannya dengan kehidupan sosial kemasyarakatan.

Tujuan pendidikan bersifat abstrak karena memuat nilai-nilai yang sifatnya abstrak.Tujuan demikian bersifat umum, ideal, dan kandungannya sangat luas sehingga sulit untuk dilaksanakan di dalam praktek.Sedangkan pendidikan harus berupa tindakan yang ditujukan kepada peserta didik dalam kondisi tertentu, tempat tertentu, dan waktu tertentu dengan menggunakan alat tertentu.

\section{METODE PENELITIAN}

\section{Sumber Data}

Sumberdata adalah semua informasi yang diperlukan untuk menjawab masalah penelitian. ${ }^{7}$ Adapun yang menjadi sumber data dalam penelitian ini adalah sesuai dengan fokus penelitian ini adalah dari orang tua murid yang memiliki motivasi menyekolahkan anaknya di MIN karang Baru Mataram,

\footnotetext{
${ }^{7}$ Supardi, Metodologi Penelitian, 2006, (Mataram: Yayasan Cerdas Press). HIm, 87
} 
tidak terlepas juga dari pihak pengelola pendidikan MIN karang beru mataram, diantaranya adalah kepala Madrasah, Waka Kesiswaan, Tata Usaha, dan guru.

\section{Prosedur Pengumpulan data}

Adapun prosedur pengumpulan data dalam penelitian ini adalah dengan beberapa cara di antaranya sebagai berikut:

\section{a. Metode Observasi}

Metode ini bertujuan supaya peneliti melihat secara langsung apa saja yang akan diteliti di lapangan guna mendapatkan data yang obyektif ${ }^{8}$, adapun yang diobservasi adalah proses kegiatan pembelajaran dan lain sebagainya yang terkait dengan hal yang dapat memotivasi orang tua.

b. Metode Wawancara

Adapun yang diwawancara adalah orang tua siswa, kepala Sekolah, Waka Kesiswaan, dan tata usaha, dan guru yang terkait.

c. Metode Dokumentasi

Metode ini bertujuan untuk melengkapi data yang belum diperoleh melalui metode observasi dan wawanca.

\section{HASIL PENELITIAN DAN BAHASAN}

Adapun hasil penelitian dalam penelitian ini adalah sebagai berikut:

a. Faktor yang mempengaruhi Motivasi orang tua menyekolahkan anaknya di Madrasah Ibtidaiyah Negeri Karang Baru Mataram.

Madrasah adalah kebanggaan bangsa tercinta ini, madrasah lahir karena inisiatif masyarakat bukan dari pemerintah sehingga masyarakat sendiri yang berkorban moril dan materil untuk menghidupi dan mengembangkannya. Rasa kepemilikan yang begitu kuat ini membuat masyarakat berharap penuh agar madrasah tersebut tetap survive dan berkembang, sehingga menjadi kebanggaan.

\footnotetext{
${ }^{8}$ Beni Ahmad, Metode Penelitian, hlm. HIm 186
} 
Sayangnya banyak lembaga pendidikan berorientasi madrasah tertinggal jauh dari sekolah-kolah umum. Tidak sedikit opini publik bahwa lembaga pendidikan adalah lembaga pendidikan yang ketinggalan zaman dan identik dengan keterbelakangan. Masyarakat secara umum enggan memasukkan anaknya karena khawatir anak-anaknya dikemudian hari tidak siap berkompetisi dalam tantangan globalisasi.

Presepsi yang kurang menyenangkan dari sebagian masyarakat ini tidak perlu direspon berlebihan, apalagi membuat kita ikut melakukan hal tersebut, bahkan yang harus kita lakukan adalah yang sebaliknya yaitu lembaga pendidikan madrasah harus merasa tertantang, untuk menjawab semua opini yang minor tersebut, dengan menjadikannya batu loncatan kepada posisi yang lebih dari semua anggapan tersebut dengan langkahlangkah serius untuk meningkatkan kualitas lembaga pendidikan madrasah dalam segala aspek dengan satu konsep agama bahwa lembaga pendidikan berbasis madrasah adalah termasuk dalam amal usaha fisabilillah maka semua yang terkai dalam lingkup madrasah itu harus berjuang dengan sungguh- sungguh dengan segenap jiwa raga, ini satu bukti mukmin yang sebenarnya, hal ini telah di isyaratkan dalam al-Qur'an surah al-anfal ayat 74:

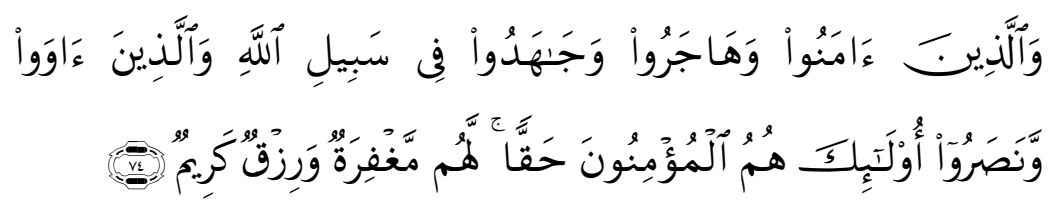

Artinya; Dan orang-orang yang beriman dan berhijrah serta berjihad pada jalan Allah, dan orang-orang yang memberi tempat kediaman dan memberi pertolongan (kepada orang-orang muhajirin), mereka Itulah orang-orang yang benar-benar beriman. mereka memperoleh ampunan dan rezki (nikmat) yang mulia. (Q.S. Al-Anfal: 74).

Terkait dengan hal tersebut untuk menjawab semua anggapan masyarakat yang kurang baik tentang lembaga pendidikan di madrasah maka 
dalam penelitian ini telah ditemukan banyak sekali prestasi, kemajuan dan kesuksesan lembaga pendidikan madrasah dalam segala aspek mulai dari peningkatan kualitas guru, kurikulum, pengembangan bakat anak didik, perluasan jaringan kerja sama, hingga pengadaan sarana dan prasaran yang baik.

Dari hasil observasi lapangan dan hasil wawancara sebagai sampel dari 20 orang wali murid ditemukan lima puluh persent $50 \%$ yang berpendapat bahwa orang tua menyekolahkan anak-anaknya di lembaga pendidikan madrasah (MIN kargang Baru mataram). Beberapa hal yang dimaksud adalah sebagai berikut:

\subsection{Kurikulum Madrasah}

Bahwa kurikulum yang dipakai di MIN Karang Baru Mataram adalah kurikulum yang memadukan bidang studi umum dan agama (kurikulum yang diterbitkan oleh Kementrian Pendidikan Nasional dan Kementrian Agama). Dengan menggunakan kurikulum ini peserta didik mendapatkan pengetahuan dalam bidang umum dan tidak kalah pentingnya dalam masalah agama terlebih lagi pada era globalisasi ini, wawasan yang bermuatan agama dan akhlak harus ditanamkan kepada generasi semenjak dini, (wawancara dengan bapak Iqbal; guru MIN Karang Baru).

Adapun kurikulum yang diselenggarakan di MIN Karang Baru Mataram terbagi dalam kurikulum intrakurikuler, kokurikuler dan ekstrakurikuler.

a. Kurikulum Intrakurikuler

Kegiatan intrakurikuler adalah proses pembelajaran yang pada umumnya dilakukan dalam bentuk in class session program, di mana tenaga pengajar terlibat secara langsung dengan system klasikal. Secara umum materinya adalah dari pelajaran yang bernaung pada departemen 
Kementrian Pendidikan Nasional dan Departemen Agama. Dengan senantiasa mengikuti perkembangan kurikulum nasional.

b. Kurikulum kokurikuler

Kegiatan ini merupakan kegiatan tambahan bagi para siwa-siswi yang wajib diikuti meski tidak harus berada di dalam kelas. Berikut ini adalah beberapa kurikulum kokurikuler: kegiatan latihan berpidato. Dalam hal ini MIN Karang Baru Mataram sering mengikuti lomba Pildacil dan mendapatkan prestasi, pembinaan pembacaan al-Qur'an yang dilaksanakan tiga puluh menit sebelum pelajaran dimulai, dari pukul 07.00-07.30, praktek amal ibadah, disiplin dalam setiap aturan sekolah.

c. Kurikulum ekstrakurikuler

Adapun kegiatan ekstrakurikuler ini, beradasarkan wawancara bahwa orang tua juga termotivasi sejumlah 10\%. Karena ini adalah proses pembelajaran pendukung yang mana orang tua tidak terlalu focus pada hal ini. Pembelajaran ini dalam bentuk off-Class session, meski juga melibatkan guru atau pelatih. Kegiatan ini diupayakan untuk menyalurkan dan mengembangkan minat serta bakat siswa-siswi. Berikut ini adalah beberapa kegiatan ekstrakurikuler: diskusi dan kegiatan laboratorium, pengembangan olahraga, pengembangan seni musik melalui (drum band, dan qosidah); pengembangan seni bela diri (karate, taekwondo); pengembangan teater, jurnalistik (madding siswa).

\subsection{Sistem Akademik}

Adapun aksentuasi dari kegiatan di MIN Karang Baru Mataram adalah pembelajaran berbasis pengalaman, realitas dan keteladanan. Pembelajaran berbasis pengalaman adalah menggali seluas mungkin pengalaman yang dimiliki siswa maupun para guru, realitas lapangan adalah dengan memberikan contoh-contoh konkrit tentang kondisi di lapangan untuk diambil hikmah dan intisari yang bermanfaat, adapun 
keteladanan adalah bagaimana guru dapat memberikan kontribusi yang positif dalam membentuk karakter (caracter building) siswa melalui contoh (figur) yang utuh yakni bagaimana cara bersikap maupun bertutur kata yang baik.

Dengan berbekal ketiga aspek tersebut, diharapkan MIN Karang Baru Mataram dapat berdiri lebih maju dibandingkan dengan SD dan memiliki nilai lebih di bidang agama baik dalam segi pengetahuan maupun praktek kesehariannya. Atau dapat diistilahkan bahwa sistem akademik di MIN Karang Baru Mataram yaitu dengan dua sistim yang pertama jalur ajar (proses pembelajaran), dan jalur qiroati (khusus belajar membaca al-Qur'an dari tingkat dasar sampai tingkat yang lebih tinggi) istialah ini disebut jalur asuh ${ }^{9}$.

Dari hasil wawancara bahwa Sistim akademik Qiroati memotivasi orang tua sebanyak $40 \%$, ini inilah yang menjadi nilai tambah bagi MIN Karang Baru Mataram yang sesungguhnya tidak ditemukan di MIN yang lain di Mataram. Dari hasil wawancara dengan beberapa wali murid bahwa program inilah yang sangat memotivasi orang tua menyekolahkan anaknya di MIN Karang Baru, dan sesungguhnya tidak terlepas dari beberapa aturan yang ada, (wawancara: ibu Eka; wali murid, dari Gunung Sari).

1.3. Program Pendidikan

Penyelenggaraan pendidikan di MIN Karang Baru Mataram dimulai sejak tahun 1965 yang bernaung di bawah Yayasan Darul Ulum, dimana perjalanannya dari tahun ke tahun berkembang sangat lamban, sehingga pada tahun 1996 oleh

\footnotetext{
${ }^{9}$ Jamal ma'mur, Kiat Melahirkan Madrasah Unggulan,2013 (Jogjakarta: Diva Press), hlm, 168.
} 
pengurus Yayasan sepakat menyerahkannya kepada pemerintah dalam hal ini Departemen Agama untuk dinegerikan. ${ }^{10}$ Pendidikan formal tersebut sebagai implementasi dari misi lembaga MIN Karang Baru Mataram yaitu:

- mendorong semangat belajar,

- Menumbuhkan sikap bersih, rapi, dan disiplin,

- Menumbuhkan sikap tutur kata dan prilaku yang Islami,

- Mendalami pembelajaran Bahasa Indonesia, Arab dan Inggris.

- Bekerja dengan prinsip kebersamaan dan bertanggung jawab.

- Membangun semangat musyawarah dan mufakat.

- Melaksanakan tugas dengan prinsip keterbukaan dan kejujuran.

- Mendorong kreatifitas siswa siswi, guru dan pegawai.

- Berkoordinasi, berkomunikasi dengan masyarakat dan instansi terkait.

\section{b. Harapan Orang Tua setelah anaknya di sekolahkan di Madrasah Ibtidaiyah Negeri Karang Baru Mataram.}

Harapan dari orang tua sehingga memasukkan anaknya di MIN Karang Baru Mataram adalah pada dasarnya tiada terlepas dari kesuksesan dalam pendidikan dalam segala aspek baik itu segi rohani, kecakapan dalam keilmuan umum dan berakhlaq mulia. Orang tua mengharapkan agar anaknya memiliki kemampuan dasar agama saat mereka melanjutkan ke jenjang Mts yang merupakan kelanjutan dari MI.

Kesimpulan dari harapan orang tua adalah agar anak-anak mereka pendidikan memiliki kemampuan dalam bidang agama dan

${ }^{10}$ Profil Madrasah Ibtidaiyah Karang baru Mataram lingkunganKarang Baru Suradadi Kecamatan Selaparang Kota Mataram Propinsi NTB. 
umum yang tidak akan didapatkan pada sekolah-sekolah dasar/SD, yang waktu pelajaran agama hanya 2 jam dalam seminggu.

\section{c. Peran lembaga pendidikan Madrasah Ibtidaiyah Negeri Karang Baru} Mataram.

Adapun peran dari lembaga pendidikan di MIN Karang Baru Mataram tercermin dari visi misi MIN Karang baru mataram dengan visi “Terwujudnya Siswa Yang Berprestasi, Terampil, Mandiri dan Islami” dan salah satu misi yang mengarah kepada perannya dengan lingkungan luar madrasa adalah Berkoordinasi, berkomunikasi dengan masyarakat dan instansi terkait.

Peran tersebut dapat dikelompokkan kedalam dua peran yaitu:

- Peran kemasyarakatan dan;

Dalam peran ini, madrasah tidak ubahnya miniature masyarakat atau dunia kecil, gambaran nyata kehidupan tempat santri belajar hidup sebelum hidup pada dunia yang sesungguhnya. Para siswa dididik mulai dari kebersihan sampai menjadi pelaksana sebuah kegiatan.

Dengan upaya ini, harapannya, apabila mereka nanti terjun dalam masyarakat dimanapun dirinya berada dan apapun bentuk masyarakatnya akan tumbuh rasa peraya diri danmudah berdaptasi, begitu pula erbdalam menekuni berbagai propesi yang ada.

- Peran ibadah dalam mencari ilmu

MIN Karanag Baru Mataram menanamkan dalam diri para siswanya keyakinan untuk menuntut ilmu dengan niat yang suci, yaitu ibadah untuk memenuhi perintah Allah SWT, dalam hal ini MIN Karang Baru Mataram diharapkan akan menjadi basis dasar dalam menciptakan teknologi dalam bidang ilmu umum dan agama, dengan demikian setiap siswa akan memiliki peluang dan kesempatan serta sarana dasar untuk mengembangkan bakat dan minatnya. 


\section{E. SIMPULAN}

Dari paparan hasil penelitian dan bahasannya tersebut dapat disimpulkan bahwa motivasi orang tua yang menyekolahkan anaknya di MIN Karang Baru Mataram adalah terletak pada beberapa hal sebagai berikut diantaranya adalah Kurikulum madrasah yang mengacu pada pembelajaran yang berbasis pada keterpaduan antara bidang studi umum dan agama dengan sistim ekstrakurikuler yang menjadi nilai tambah bagi MIN Karang baru Mataram yaitu sistim Qiroaty yang diprogramkan sebagai wahana pembinaan pembacaan al-Qur'an sesuai tingkat atau kelas para siswa yang dilaksanakan tiga puluh menit sebelum pelajaran dimulai, dan dilengkapi dengan program praktek amal ibadah. Hal inilah yang menjadi motivasi orang tua yaitu mengharapkan putra-putrinya memiliki ilmu agama dan umum yang menjadi bekal dasar untuk melanjutkan pada jenjang pendidikan yang lebih tinggi dan dapat menjaga diri dalam pergaulan di masyarakat.

\section{F. DAFTAR PUSTAKA}

Abror, Abd Rachman. 1993. Psikologi Pendidikan. Yogyakarta: Tiara Wacana.

Anonim,1978.Al-Qur'an dan Terjemahnya.Jakarta : Depag RI. Anonim, Tim Dosen FIP-IKIP Malang, 1988. Pengantar Dasar-dasar Penddikan.Surabaya : Usaha Nasional.

Anonim, 2003. Undang-undang SISDIKNAS (Sistem Pendidikan Nasional). 2003. Jakarta :Redaksi Sinar Grafika.

Arikunto, Suharsimi. 2005. Manajemen Penelitian.Rineka Cipta: Jakarta.

Faisal, Sanafiah. 1990. Penelitian Kualitatif Dasar-dasar dan Aplikasi.Malang : Arruz Media.

Mansyur. 1997. Strategi Belajar Mengajar. Jakarta : Dirjen Pembinaan Kelembagaan Agama Islam / Depag RI.

Mukhtar.2003. Desain Pembelajaran Pendidikan Agama Islam.Jakarta : CV Misaka Galiza. 
Moeslichatoen.1999. Metode Pengajarn di Taman Kanak-Kanak.Jakarta: Rineka Cipta.

Nasution.2000. Didaktis Asas-asas Mengajar.Jakarta ; Bumi Aksara.

Rakhmad, Jalaluddin. 1994. Psikologi Komunikasi. Bandung :Remaja Rosda Karya Offset.

Singarimbun, Masri dk. 1983. Metode Penelitian Survei. Jakarta:LP3ES.

Sugiyono, 2010. Metode Penelitian Kuantitatif Kualitatif dan R\&D.Bandung: Alfabeta.

Sukandarrumidi. 2002. Metodologi Penelitian.Yogyakarta: Gadjah Mada Universti Press.

Syalthut, Muhammad. 1990. Tafsir Al-Qur'anul Karim.Bandung ; Diponegoro.

Tafsir, Ahmad. 1992. Ilmu Pendidikan dalam Prospektif Islam.Bandung ; Remaja Rosda Karya.

Syah, Muhibbin.1995. Psikologi Pendidikan.Bandung: Remaja Rosda Karya. Syarifuddin, Amir.2008.Mendidik Anak Membaca, Menulis, dan Mencintai Al Qur'an, Jakarta: Gema Insani. 